\title{
Stage II Soft Tissue Sarcoma of the Trunk and Extremities AJCC v8
}

National Cancer Institute

\section{Source}

National Cancer Institute. Stage II Soft Tissue Sarcoma of the Trunk and Extremities

A/CC v8. NCl Thesaurus. Code C136701.

Stage II includes: T1, NO, M0, G2, G3. T1: Tumor measuring $5 \mathrm{~cm}$ or less in greatest dimension. NO: No regional lymph node metastasis or unknown lymph node status. M0: No distant metastasis. G2: Total differentiation, mitotic count and necrosis score of 4 or 5. G3: Total differentiation, mitotic count and necrosis score of 6, 7, or 8. (AJCC 8th ed.) 